\title{
Eurozone crisis and emerging market expansion: Capital switching and the uneven geographies of Spanish urbanization
}

Dol:

10.1111/1468-2427.12402

\section{Document Version}

Accepted author manuscript

Link to publication record in Manchester Research Explorer

Citation for published version (APA):

Kutz, W. (2016). Eurozone crisis and emerging market expansion: Capital switching and the uneven geographies of Spanish urbanization. International Journal of Urban and Regional Research, 1-49.

https://doi.org/10.1111/1468-2427.12402

\section{Published in:}

International Journal of Urban and Regional Research

\section{Citing this paper}

Please note that where the full-text provided on Manchester Research Explorer is the Author Accepted Manuscript or Proof version this may differ from the final Published version. If citing, it is advised that you check and use the publisher's definitive version.

\section{General rights}

Copyright and moral rights for the publications made accessible in the Research Explorer are retained by the authors and/or other copyright owners and it is a condition of accessing publications that users recognise and abide by the legal requirements associated with these rights.

\section{Takedown policy}

If you believe that this document breaches copyright please refer to the University of Manchester's Takedown Procedures [http://man.ac.uk/04Y6Bo] or contact uml.scholarlycommunications@manchester.ac.uk providing relevant details, so we can investigate your claim.

\section{OPEN ACCESS}




\section{Eurozone crisis and emerging market expansion: Capital switching and the uneven geographies of Spanish urbanization}

William Kutz, School of Environment, Education and Development, University of Manchester, Manchester UK

\section{Abstract}

The theory of capitalist urbanization posits that the built form serves as a crucial sink through which overaccumulated capital is "switched" from industrial production into long-term investments in urban infrastructure. Since Harvey's (1978) deployment of the theory, researchers have attempted to empirically substantiate the switching thesis with limited success. Christophers (2011) revisited the debate with new data and methods to support the claim that significant investment had switched into the built environment at the onset of the 2007-08 financial crisis. However, Christophers' study overlooks how crises are also geographically displaced. This article analyzes Spanish trade data for the years 1993-2013, the years prior and subsequent to the housing-induced economic crisis (1997-2006). Two studies are undertaken. The first replicates Christophers' methodology to assess how and to what extent a sectoral switch into property investment occurred in Spain between 1997 and 2006. The second modifies the methodology to investigate the extent to which overaccumulated capital in Spain was geographically displaced through investment in the Moroccan building industry since 2006. These approaches situate uneven development (geographical switching) and turnover time (sectoral switching) as the twin dynamics through which capitalist urbanization is spatiotemporally fixed.

\section{Keywords}

capital switching, urban process, uneven development, crisis, Spain, Morocco 
Introduction

The Urban Process is a Lefebvrian-inspired framework advanced by Harvey (1978) to conceptualize the role that the built environment serves in the regulation and reproduction of capitalist accumulation. The theory hinges upon the category of "capital switching" and while enormous literature bears on it, little research has directly assessed the concept. Attempts to empirically substantiate the switching thesis in the decades since Harvey's initial formulation proved remarkably difficult (King, 1989; Beauregard 1994). Results often showed little to no evidence to support Harvey's claims, despite his continued deployment of the theory (Harvey, 2008; Harvey, 2012). In this context Christophers (2011) revisited the decades-long debate in an effort to shed explanatory light on the recent financial crisis. His findings are arguably the first to provide persuasive evidence that between 2000 and 2007, significant investment in the United Kingdom and the United States diverted from the industrial sphere into the construction and property sectors.

This research nevertheless remains incomplete. Christophers only explains one side of Harvey's formulation: sectoral switching between industry and the built environment. Case studies from the UK, USA, Ireland, and Canada are presented, but the focus centers upon comparing the temporal dynamics of investment in infrastructure rather than on the uneven flows of capital between different geographical locations. Indeed, Harvey's own redeployment of the theory since the crisis has explicitly sought to inflect a more geographical interpretation of the switching thesis despite limited empirical evidence (Harvey, 2008; Harvey, 2010). This presents a gap in knowledge critical to explaining the geographical modalities 
of economic crises and urbanization that remains unanswered nearly a decade since the recession.

The crucial issue in previous switching research (c.f. Harvey, 1978; King, 1989; Beauregard, 1994) centered upon explaining the functional relationship between industrial production and the built environment as either interdependent or independent of the other in regulating accumulation. This research spatializes the question by investigating how and to what extent the geographical displacement of capital is related to sectoral switching crises. If, as Harvey (2008) argues, emerging property markets have increasingly served as a necessary sink to "fix" unproductive capital, then we would expect to find such evidence in places most affected by the recession. This article examines Spanish foreign direct investment (FDI) to Morocco as a representative case study. The Spanish housing bubble was an important contributor to the 2007-08 economic crisis in the European Union. In 2006, the building industry employed 13 percent of the Spanish workforce and had more units under construction than in Germany, France, Italy, and the UK combined (Henn et al., 2009). At its height, the construction sector represented 10 percent of GDP - twice that of the USA (Gonzalez and Ortega, 2010; Romero et al., 2012). Morocco is one of Spain's largest trade partners and is the leading destination for Spanish capital on the African continent (Valle Muñoz, 2007). This position is relatively recent and emerged from extensive liberalization programs implemented by the Moroccan State since the early 2000s, in part, in an attempt to gain membership into the European Union (Casas-Cortes, et al., 2012). The growth of these and other institutional linkages and geo-economic initiatives with Spain at the onset of the housing crisis 
have played a decisive role in transforming Morocco into what Ambassador Luis Planas called a "privileged and strategic partner" of the Spanish economy (Filali, 2009: 3).

The objective of this study is to examine how and to what extent this shift in Spanish capital was related to the collapse of the domestic housing market. The article presents compelling evidence that the Spanish housing crisis precipitated a significant geographical switch in investment to the Moroccan building industry. These findings situate overaccumulation in the built form as a force propelling the geographical displacement of capital to Morocco's emerging property market. The findings nuance existing research on sectoral switching and offer an entry-point into understanding the relationship between the temporal dynamics of accumulation the regulation of turnover time - and the uneven spatial patterning of investment in the built environment (Smith, 1982; Harvey, 1984; Aalbers, 2009a; Aalbers, 2009b; Harvey, 2008; Christophers, 2011).

The article has four parts. The first section investigates the theoretical assumptions made in previous research on capital switching and asserts the need for a more geographically attuned framework. The second section explains Christophers' methodology on sectoral switching, and develops a geographical approach to interpreting the crisis in Spain. The third section explains the findings of the sectoral and geographical approaches to capital switching, and advances the argument that not only did a significant switch occur within the Spanish economy, but that since 2006, FDI to Morocco disproportionately concentrated in the local building industry. The article concludes by revisiting the concept of geographical 
capital switching and discussing what the findings offer contemporary urban research.

\section{Geographies of Capital Switching}

Marxist theorization of urbanization centers upon a conception of capital switching that Harvey developed in a series of articles throughout the 1970s (Harvey, 1974; Harvey, 1975; Harvey, 1978). In its advanced framework, capital switching represented two distinct but interrelated responses to crises of overaccumulation. On the one hand, sectoral switching referred to a shift in investment from less to more productive economic spheres. On the other hand, geographical switching involved rechanneling capital from one place to another (Harvey, 1978). Christophers (2011), following Beauregard (1994), centered his analysis upon sectoral switching and elides its geographical variant. The reason stems from Christophers' strict reading of the theoretical framework, which sustained many assumptions Harvey held to construct an explicitly Marxist theory of urban change.

When Harvey (1978: 101) opened his article with the objective to "understand the urban process under capitalism," the statement belied his rejection of established urban theory. Throughout the 1950s and 1960s, urban researchers were confronted with the fact that urban theory was increasingly incapable of explaining the spatial dispersion of post-war urbanization in industrialized states. Hoyt (1964) argued that his own sectoral model and other Chicago School "classics" required substantial revision to effectively explain the unprecedented changes occurring in the American 
landscape. The issue was that urban development proliferated in areas that lacked significant industries or markets around which settlements were presumed to agglomerate (c.f. Weber, 1929; Christaller, 1933). Friedmann and Miller (1965) argued this pattern represented the emergence of a "post-industrial society":

“[In] the next generation, we foresee a new scale of urban living that will extend far beyond existing metropolitan cores and penetrate deeply into the periphery. Relations of dominance and dependency will be transcended. The older established centers, together with the inter-metropolitan peripheries that envelop them, will constitute the new ecological unit of America's postindustrial society that will replace traditional concepts of city and metropolis" ( $\mathrm{p}$. 313, my emphasis).

The Urban Process refuted this "post-industrial" claim by arguing that the relationships between cities and industry were superficial manifestations of underlying processes of capitalist accumulation. To make this point, however, Harvey argued that the built environment was not simply a site through which capital was consumed, but served a necessary productive purpose. The logic shaping investment in the built form was defined by the particular role of turnover time in fixed capital investment vis-à-vis other economic sectors. Harvey drew upon Marx's insights from Capital, Volume 2, to argue that fixed capital, and by extension urban infrastructure, had longer turnover times than other factors of production. An acceleration of accumulation in industrial production could be temporarily regulated through long-term investments in the built form. Switching could be distinguished 
from processes of everyday circulation by linking cycles of urban investment to historic crises of overaccumulation. Hence, Harvey concluded:

\begin{abstract}
"Each of the global crises of capitalism was in fact preceded by the massive movement of capital into long-term investment in the built environment as a kind of last ditch hope for finding productive uses for rapidly overaccumulating capital" (Harvey, 1978: 120).
\end{abstract}

Geographical switching was under-theorized in this context. The geographical concentration of fixed capital differentially impacts an investment's productive potential. Yet, Harvey's only substantive engagement with geographical switching was a brief mention of inversely correlated property investment between the UK and USA during the $19^{\text {th }}$ century (Harvey, 1985: 77-8). Beauregard (1994) argued in this context that space played a minor role in the Urban Process because: "given [Harvey's] concern with urbanization, [he] focuses solely on the switching of capital from the primary to secondary circuit" (p. 718). This misses a critical point. For Harvey, only sectoral switching could demonstrate the necessary productive function of the built environment in regulating the temporal accumulation of capital. Geographical switching did not provide the same law-like tendency because although "Marx's general theory tells us of the necessity to expand and intensify geographically, [...] it does not tell us exactly how, when or where" (Harvey, 1975: $18)$.

Harvey (1978) was keenly aware of the potential limitations sectoral switching placed on his framework. In a concluding remark to this article he states: 
"I have been forced to blur distinctions, make enormous assumptions, cut corners, jump from the theoretical to the historical in seemingly arbitrary fashion and commit all manner of sins which will doubtless arouse ire and reproach as well as a good deal of opportunity for misunderstanding" (Harvey, 1978: 130). In the years between the publication of the Urban Process and its reappearance in The Urban Experience (1985), the text is identically reproduced. The only omission is this concluding remark, which suggests that Harvey did not see fit to alter his stance on the geographical dynamics of capital switching despite important advancements made on theories of uneven development by others since that time (Walker, 1981; Smith, 1982; Massey, 1984; Gottdiener, 1985).

This tension in Harvey's framework shaped subsequent research on the switching thesis in two ways. One body of research sought to substantiate the degree to which the built environment and the secondary circuit of capital were autonomous from the sphere of industrial production (Beauregard, 1994). Other research explicitly aimed to incorporate a theory of uneven development into analyses of urban change. Sectoral research centered upon substantiating the relationship between the first and second circuits of capital. Feagin (1987) built upon Gottdiener (1985) to argue that investment in real estate was more autonomous from industrial production than suggested in the Urban Process because Harvey failed to acknowledge "that land has its own dynamic... independent of problems in the primary circuit" (p. 173). Feagin's research investigated investment flows in Houston's oil and building sectors during the 1980s and found that "only a small proportion of the surging oil company ('windfall') profits actually flowed into US 
real estate, including Houston area development projects" (Feagin, 1987: 182). Feagin did not claim that industrial production and building investment cycles were unrelated, but that their relationship could not be substantiated because the complexity of institutional investment blurred clear lines of causality. Beauregard (1994), however, identified a more basic contradiction in Harvey's thesis. He argued that Harvey's assertions about the functional relationship between industry and the built form in The Limits to Capital (1982) and The Condition of Postmodernity (1989) took on both an increasingly deterministic and independent character:

"Overall, through the emphasis on cyclical behavior, Harvey implies that [sectoral] switching is dependent upon conditions within the sphere of production. However, by his recognition of financial intermediaries and derivative claims of an autonomous secondary circuit, he establishes a case for the cyclical behavior of construction investment to occur independently of conditions in the primary circuit" (Beauregard, 1994: 719 - author's emphasis).

Beauregard's study was an attempt to reconcile these dissonant claims by analyzing the plausible productive necessity of sectoral switching during the 1980s housing boom in the United States. He nevertheless found inconclusive evidence of a relationship. Like Feagin, plausible correlations were difficult to establish precisely because investment institutions could facilitate the displacement of overaccumulated capital into other financial outlets beyond the built form. In the aftermath of the 
2007-08 financial crisis Christophers recognized that analysis of capital switching needed to directly investigate (rather than conceptually separate) capital markets to substantiate the switching thesis. His analysis is arguably the first to demonstrate a strong plausible link between crises of industrial productivity and the displacement of overaccumulated capital into the built environment. Through this study an important step was achieved in explaining the cyclical dynamics the switching thesis to date.

However, Chistophers' research only addresses half of the problem. He does not incorporate a theory of geographical development into his analysis of sectoral change, which makes his conclusions incomplete. Prior to Beauregard's (1994) study, early research on capital switching explicitly sought to incorporate uneven development into the switching thesis. Many of these interventions came from Harvey's own students. For example, Walker's (1981) research on suburbanization demonstrated that the spatial dispersion of low-density settlements was crucial to generate the effective demand necessary for post-war economic growth in United States. Smith's $(1982 ; 1987)$ research on gentrification is perhaps the most wellknown effort to spatialize the switching thesis. Christophers notes that Smith viewed rent gaps as a "leading edge" in switching crises. In Smith's (1987) debate against behavioral interpretations of gentrification, he argued that crux of urban change did not center upon explaining middle-class demand. Rather, it turned on the "demand structures" that transformed blighted urban areas into highly profitable "inner-city spatial fixes" (Smith, 1987; Wyly et al., 2004). The exploitation of under-valorized 
"rent gaps" became the mechanism through which to spatialize the productive potential necessary to "fix" overaccumulated capital in the built environment.

It is partly for this reason that Feagin's (1987) critique of The Urban Process stemmed from a perceived lack of analysis of land ownership and rent in the dynamics of urban development. King (1989: 446) also argued that Harvey neglected ground rent in defining the process through which investment in urban infrastructure took place, which made the theory "especially problematic" and “overly deterministic." In response, King's case study centered upon a large longitudinal study of Melbourne's housing market (1930s-80s) to assess the way land markets influenced the cyclical relationship between the primary and secondary circuits of capital. Although he concluded that ground rent played a defining role in conditioning the flows of investment into and out of residential real estate, he maintained that no clear link existed between industrial and fixed capital investment.

Christophers discounted the effectiveness of King's research methods. King centered his analysis only on Melbourne's housing market and made suppositional conclusions about the relationship between crises of overaccumulation and real estate construction. To this, it should be added that King's concept of geographical switching was identical to Smith's theory of gentrification. The same can also be said for Charney's $(2001 ; 2003)$ later attempts develop an explicitly geographical theory of capital switching. For Christophers (2011), such rent-based approaches to the study of capital switching are problematic because "the rental economy is not only inextricably bound up but is in some respects part of the economy of the built 
environment, which is precisely the economy whose investment we are attempting to compare with the investment trajectory in the productive economy" (p. 1362, note 4). In part for these reasons, Christophers chose not to substantiate the geographical dynamics of accumulation.

Rent is indeed a problematic category for operationalizing geographical switching, but for a more fundamental reason. The rent gap, as an analytical category, can only explain why investment privileges certain geographical locations over others. It cannot explain what prompts the necessity for a "spatial re-emphasis" of urban investment in the first place (Smith, 1987: 164). The conceptual force of Harvey's thesis centered upon explaining the underlying structural conditions that compelled investment transfers from one economic sector or geographical location into another. Rent problematizes the geographical contingency of investment opportunities, but not the imperatives that trigger a switch (Walker and Storper, 1985). ${ }^{i}$ Geographical switching cannot be divorced from the temporal dynamics of accumulation precisely because these processes occur in and through space. Hence, my contribution to this debate is to theorize Spanish investment in Morocco as a consequence of the broader crisis tendencies in the Spanish housing market. I provide new data to assess the geography of capital switching into Morocco's urban landscape, and by extension will explain the underlying relationship between the temporal accumulation of capital and its geographical displacement.

\section{Methodology}


It is important to note that any attempt to empirically substantiate the switching thesis requires a simplification of complex socio-economic phenomena. Christophers (2011: 1350-51) detailed the methodological problems with previous research. The two issues he stressed readers bear in mind are: (a) research can never demonstrate direct, causal "proof" of switching because the economic and social relations implicated in such a dynamic are too complex to be "fully reducible to accurate and unambiguous representation in quantitative data"; (b) even if research could hypothesize credible empirical pathways, there is simply not enough data to properly chart the process in adequate detail (p. 1351). Such constraints must be taken seriously, but should not preclude continued effort to develop better methods to explain the spatial dynamics of capital accumulation and crises. Hence, this study acknowledges and brackets these methodological limitations in order to investigate geographical switching on the terms advanced in the literature. The analysis develops a geographical interpretation of switching in two ways. First, the article replicates Christophers' sectoral methodology with data from Spain to substantiate comparisons and divergences between his research findings and the current case study. Christophers' method centered upon two "tests" to analyze the plausible degree to which a shift in investment occurred from the industrial sphere into the built environment. His first test examined temporal changes in the ratio of investment in factors of production allocated to the built environment relative to all other productive investments: a first-order analysis premised upon Harvey's (1978) initial assumption that the first and second circuits of capital were functionally interdependent (Feagin, 1987; King, 1989; Beauregard, 1994). Investment in the built 
environment was measured as the total share of gross fixed capital formation (GFCF) allocated to buildings ("infrastructural investment"). Productive investments comprised all remaining investment in GFCF ("non-infrastructural investment") plus total expenditures dedicated to labor. Temporal changes in the proportion of investment allocated to the productive sector and built environment functioned as proxies to designate the degree to which built environment served as a sink to fix overaccumulated capital. Christophers' second test examined sectoral switching in the built environment as a process mediated by financial institutional investment the critical issue raised by both Harvey (1982) and Beauregard (1994). This secondorder analysis examined the tendency for institutional investors (i.e. money managers, investment funds, pension funds) to manage corporate securities dedicated to infrastructural assets over other financial activities. Changes in the amount of real estate assets under management served as proxies to interpret a switch into or out of the built environment.

The second half of this study spatializes Christophers' methodology to draw more explicit links between crises of overaccumulation in Spain and the geographical displacement of capital to the Moroccan building industry. By disabusing ourselves of the need to represent geographical switching through Smithian rent/price differentiation, alternative metrics can be employed to test the switching thesis. This study examines capital switching to Morocco using foreign direct investment data.

Foreign direct investment (FDI) comprises aspects of both international trade in goods and cross-border financial flows. Feenstra (2007: 332) noted that "there is a good deal of confusion about even the most elementary aspects of FDI, such as who 
is investing, where, how much, and why." Part of the confusion, he argues, is due to contradictory data collection techniques employed across states as well as basic conceptual misunderstandings about FDI. Money and commodities flow across borders in many forms, but FDI typically refers to direct or indirect ownership or control by a single firm of at least 10 percent of an incorporated or unincorporated foreign affiliate. ${ }^{\text {ii }}$ Gross investment flows are the funds channeled to affiliates. Net investment equals the remainder of gross capital after subtracting the amount foreign affiliates return to the parent firm (Baker et al., 2008).

An enormous literature exists on the study of foreign trade. The decision to employ trade data stems from a recent turn in the field interested in explaining "source-country" factors precipitating outward investment (e.g. Baker et al., 2008; Hill and Jonwanich, 2009; Ucal et al., 2010; Poulsen and Haufbauer, 2011; Chor and Manova, 2012). Traditional trade research centers upon understanding comparative advantages that provide opportunities for firms undertake international investment (Hill and Jongwanich, 2009). ${ }^{i i i}$ Research since the global financial crisis has challenged this focus on the locational advantages of host-countries to argue that FDI is better explained by the influence of overvalued "cheap" capital that firms seek to productively reinvest abroad. As Baker et al. (2008: 341-2) argued:

"FDI is an opportunistic use of the temporarily low-cost financial capital available to overvalued firms in the source country. [...] Managers of an overvalued acquirer know that overpricing will end eventually, but they can benefit from ongoing investors, at the expense of new ones, by issuing capital 
to buy less-overpriced assets. For firms overvalued due to a local asset price bubble, for example, candidate investments would include overseas targets that are not particularly overvalued $[\ldots] "$ (my emphasis).

This observation supports Christophers' (2011) own findings on sectoral switching prior to the onset of the European crisis, and Harvey's own attempts to spatialize contemporary urbanization worldwide. If foreign and real property investments appear to both follow a similar cyclical pattern at the onset of crises, it is worth examining the temporal relationship between the two phenomena. Trade data offers an added methodological benefit: foreign trade is foundational to geopolitical, economic and diplomatic relations for all states. Trade data is often very accessible and detailed. This means that we can separate data pertaining to the Moroccan building industry and compare it to all remaining direct investment. Spanish trade data is publicly accessible from the DataInvex investment database managed by the Spanish Ministry of Economy and Competitiveness (Ministerio de Economía y Competitividad - MEC, 2015). The database is organized according to the European "Nomenclature of Economic Activities" (NACE Rev. 2), which subdivides industrial indicators into 615 different "classes." The NACE system is detailed enough to allow us to individually separate all economic activity that could have contributed to the residential and commercial building sector. Of the 615 classes identified in the NACE, 82 were selected and regrouped in Table 1.iv The table lists all NACE classes that could plausibly represent a direct contribution to the Moroccan building industry. The designation as to what constituted a "direct contribution" to the 
building industry was left as open as possible to allow for the potential to identify investment in economic sectors beyond more evident construction or real estate activities. The majority of investment activity fell under NACE "divisions" 23, 41, 43, which broadly refer to building compounds (cement, plaster, clay production), construction activities, and real estate activities, respectively.

\section{TABLE 1 HERE}

The test devised to interpret geographical switching is a modification of the proportionality tests developed by Christophers. Put simply, the analysis examined the tendency for Spanish investment to flow into the Moroccan building industry, relative to all other sectors at the onset of the Spanish housing crisis. A disproportionate increase in building related investment to Morocco after 2006 would indicate the plausibility of a geographical switch in response to the recession. Together the two analyses help identify the temporal and sectoral dynamics shaping the geographical displacement of capital from Spain to Morocco and help explain the wider spatiality of capitalist accumulation and crisis.

\section{Analysis I - Sectoral Switching}

Private Sector Expenditure 
The analysis begins with an assessment of the relationship between investment in industrial production and the built environment. Data on GFCF and labor compensation was drawn from the Spanish Statistical Office (Instituto Nacional de Estadística) for the years 1995-2008. The timeframe corresponds to the Spanish housing bubble, which expanded approximately three years prior to the building boom in the UK and the USA. Previous research indicates that the Spanish housing bubble started in 1997 and collapsed in 2006 (García, 2010; Romero et al., 2012). For comparative purposes, and where available, the data extends to the years before 1997 and after 2006 to give a clearer picture of changing investment patterns over the entire housing cycle.

Table 2 represents the ratio of private sector spending allocated to Spanish building activity from 1995 to 2008 (Spanish Statistical Office, 2015a; 2015b). Fixed capital formation in Spain is comprised of six variables: agricultural products, metal products and machinery, transportation equipment, housing construction, other construction, and other products. The "Buildings" variable was calculated as the combined value of the two construction metrics. "Inputs" represent all remaining non-infrastructural GFCF, and "labor" as total employment expenditure. Following Christophers, the proportional growth in investment allocated to infrastructure acts as an indicator for switching into the built environment. The increase in building expenditure indicates that the total share of private sector spending increased from 16 percent in 1997 to 23 percent in 2007. In other words, during the Spanish housing bubble, private sector spending increasingly concentrated in urban infrastructure relative to all other productive industries. In absolute terms, infrastructural spending 
more than tripled from $€ 58$ to $€ 187$ billion in ten years. When adjusted for inflation, this represents a real compound annual growth rate (CAGR) of 9.05 percent over the period.

By comparison to the UK case, Christophers concluded that the ratio of infrastructural to non-infrastructural investment increased by only 2.5 percent. In absolute terms, this represented growth in expenditure from $€ 94.5$ ( $£ 58)$ billion in 2000 to $€ 135.8$ ( $£ 97$ ) billion in 2007 , or a real CAGR of 4.7 percent (Christophers, 2011: 1354). This suggests that the rate of urban infrastructural investment in Spain was more intense and long-standing than that evidenced in the UK. These findings are consistent with the literature that the Spanish housing crisis not only precipitated the wider recession in the European Union, but was also more pronounced than in other more economically stable European regions (García, 2010; Romero et al., 2012).

\section{TABLE 2 HERE}

\section{Consolidated Financial Investment}

The second test for sectoral switching investigates the changing temporal pattern of real estate assets under institutional management. Data was drawn from the OECD iLibrary dataset on institutional investor assets for Spain for the years 1995-2013. This approach takes a broader interpretation of institutional investment than that offered in previous research (Beauregard, 1994; Christophers, 2011). Specifically, Christophers (2011) examined the share of property assets under institutional 
management by pension funds. Pension funds were among the most significant institutional investors in the UK, and by examining only one type of investment vehicle he was able to infer a plausible switching of portfolio investment into the real estate sector. This study examines the total proportion of consolidated investment fund activity between financial and non-financial assets because it gives a broader indication of how the financial sector as a whole mediated investment into and out of real property. In Spain, consolidated investment funds include mutual funds, pension funds, insurance corporations, as well as real estate funds. The OECD defines non-financial assets as "tangible assets, both produced and non-produced, and most intangible assets for which no corresponding liabilities are recorded" (OECD, 2015a). Although this asset class is comparatively much smaller than securities, it is more useful for our purposes. Property is a crucial vehicle for investors to diversify and hedge against the volatilities of short-term market risk (Brueggeman et al., 1984; Zhu, 2005), and Spanish non-financial assets are almost exclusively comprised of real estate funds.

Figure 1 illustrates the changing investment pattern between financial and non-financial asset classes in Spain from 1995 to 2013. Prior to the recession, nonfinancial investment held a minor share of market activity compared to investment in securities, stocks, and currencies (OECD, 2015b). The funds accounted for less than 5 percent of trading at any given point since 1995. This, however, belies the extraordinary growth in the share of non-financial funds under management at the onset of the crisis. In absolute terms, non-financial investment increased from just $€ 2$ 
million to over $€ 7.8$ billion between 1995 and 2007. If only accounting for investment from 1999 to 2007, the real compound annual growth rate exceeded 34 percent.

Figure 1 plots this consolidated shift. From 1999 to 2007, financial investment grew 25 percent, while non-financial investment recorded a13-fold increase over the same time period. This evidence supports the claim in the Spanish literature that when the housing market began to inflate the financial industry increasingly placed real property assets under institutional management (Rodríguez López and Fellinger Jusué, 2006; García, 2010; López and Rodríguez, 2011). Similarly, the industry has held a substantial number of these assets since housing crisis, which suggests that the real estate sector continues to perform an important regulatory function in managing market volatility in the manner that Harvey (1978) initially theorized.

\section{FIGURE 1 HERE}

These observations differ from those given in Christophers' (2011) analysis of pension fund portfolio management. Direct comparisons are not possible because Christophers' study examines different types of data. To establish parity, the same asset classes were examined for the UK for the years 2000-2013, the period under investigation in Christophers' study. Clear discrepancies between the UK and Spanish financial sectors exist. In 2007, the value of UK financial assets ( $€ 760$ billion) was nearly triple that held in Spain ( $€ 270$ billion - OECD, 2015b). The share of nonfinancial assets held by the industry was also much greater in the UK, which at its height in 2006 commanded a full third of all institutional investment. When indexed, 
the data shows remarkable investment growth in the years immediately preceding the European recession. Figure 2 illustrates that financial investment increased by 86 percent between 2000 and 2007 while non-financial investment more than tripled.

\section{FIGURE 2 HERE}

Although institutional investors in the UK controlled significantly more nonfinancial assets than their Spanish counterparts, in both relative and absolute terms, comparisons between Figures 1 and 2 indicate that Spanish financial investment in real property was more pronounced and lasting. This is in part due to the unusual offloading of investment preceding Spain's economic collapse and the logic of sectoral switching as a mechanism to abate the acceleration of accumulation through long-term investments in urban infrastructure. Nevertheless, the question still remains if and to what extent this capital geographically switched in response to the Spanish crisis.

\section{Analysis II -Geographical Switching}

The second half of this study examines gross capital flows from Spain to Morocco since 1993. Trade data is often interpreted as net flows, which subtracts payments (or debits) from foreign affiliates to parent companies (Schmidt and Hackethal, 2004). Gross investment is a more useful metric for this study because our concern centers 
upon the productive potential of outward investments, regardless of their ultimate profitability or the contributions made by affiliates.

A preliminary analysis of Spanish switching indicates a weak relationship between the domestic housing crisis and outward investment. Figure 3 highlights the exceptional volatility in total foreign trade between 2000 and 2008. The most significant investment occurred in 2003, three years prior to the recession. Although two further waves of investment occurred in 2006 and 2008, the total amount transferred declined with each new round of investment. This is the opposite of what we would expect from the switching thesis.

\section{FIGURE 3 HERE}

An entirely different picture emerges when Spanish investment allocated to building activity is examined. The same figure shows that until 2006, building related investment played a sporadic, if not minor, role in Spanish foreign trade. After 2007, however, FDI disproportionately concentrated in real estate and construction activity (MEC, 2015). In absolute terms, building investment exceeded $€ 107$ million in 2007. This amount is nearly double all combined investment in the sector over the previous 10 years (1997-2006). In 2008, building investment was almost five times greater than in 2007, with substantial investments following each year through 2011. If we compare this investment as a proportion of total Spanish trade, over 60 percent targeted the Moroccan building sector between 2007 and 2010; in 2008 and 2010 the amount exceeded 90 percent of all FDI to Morocco (MEC, 2015). This proportional 
increase is tremendous when considering that, after France, Spain is the second largest trade partner with Morocco.

The significance of this geographical switch is brought into sharper relief when Spanish building investment to Morocco is compared to that directed to EU-15 member states (Figure 4). This graph, when compared to building investment in Figure 3, indicates an important, lagged relationship in Spanish trade between the two regions.v For example, from 1997 to 2005, Spanish investment to EU-15 member states recorded a 70-fold increase from $€ 86$ million to $€ 6.2$ billion, or a real CAGR of over 67 percent. After 2005, however, building investment steadily declined to $€ 470$ million by 2010 (MEC, 2015). Crucially, as investment to EU-15 economies fell, Spanish investment to Morocco increased. The relationship between the EU and Moroccan markets does not establish causality, but does help explain the significance of Morocco's "privileged and strategic position" for the Spanish economy amid the wider crisis in Europe (Filali, 2009: 3; Galindo, 2006). The trends also lend credibility to claims reported in the Moroccan press of an "Iberian invasion" driven by property speculators in the wake of the Spanish housing bubble (see e.g. Filali, 2007; Harakat, 2008).

\section{FIGURE 4}

The immediate question this raises is: what does this investment activity look like at a sectoral level? According to previous research we should expect to find investment concentrated in urban infrastructure, such as residential real estate and commercial 
building activity (Beauregard, 1994; Christophers, 2011). This is only partly the case. The largest share of investment in the Moroccan building industry after 2006 targeted cement production. This sector contributed to $€ 539$ of $€ 817$ million, or 65 percent of building related investment since 2007. Construction received the second largest share of investment, or 24 percent (€212 million) of total building activity. Specialized construction was the third largest recipient of Spanish capital, totaling $€ 41$ million, or 4 percent of investment.

From this general picture three features of Spanish investment can be identified from the trade data. First, investment to Morocco emanated from only four Autonomous Communities: Catalonia, Madrid, Galicia, and Andalusia (MEC, 2015). These regions are among the largest industrial centers and recorded some of the most extensive urbanization rates in Spain (Romero et al., 2012). In absolute terms, Catalonia was the single largest contributor to Morocco, providing 73 percent (€597 of $€ 817$ million) of all capital between 2007 and 2013. Galicia and Madrid were the second and third largest contributors with 20 and 3 percent of building investment, respectively. In relative terms, however, the largest growth in the rate of investment to Morocco during this time emanated from Catalonia, Madrid, and Andalusia. Catalonian investment increased by a factor of 22, that from Madrid grew nine-fold, and Andalusian capital tripled. Second, each of these regions articulated different forms of geographical switching (MEC, 2015). As a major industrial center of Spain, 83 percent of Catalonian investment since 2007 concentrated in cement production, with direct construction contributing the second largest share (11 percent) of regional FDI. Conversely, Andalusia has historically been the least industrialized and 
economically developed region in Spain (Entrena and Gömez-Mateos, 2000).

Housing construction was a key driver of the local economy and since 2007 over 97 percent of regional investment targeted the Moroccan construction industry (Paluzie et al., 2002). Finally, regional data indicates that Spanish investments often stayed within the same economic sector (MEC, 2015). This suggests that foreign capital was primarily used to acquire Moroccan subsidiaries within the same industry and did not flow into potentially more lucrative ventures outside the operational remit of the investing firm. This observation is consistent with findings from the trade literature because FDI measures ownership, not portfolio investment (Feenstra, 2007).

The discrepancy between investments in the concrete and real estate industries is partly due to the composition of the two sectors. The Catalonian cement industry is dominated by Lafarge Cementos, a French building materials specialist and one of Spain's largest cement manufacturers; its subsidiary, Lafarge Maroc, is also Morocco's top cement producer (Lafarge Maroc, 2015). There is no apparent Catalonian competitor in the Moroccan concrete manufacturing sector, which means most, if not all, FDI in concrete likely transferred within the Lafarge conglomerate after 2006. Conversely, the Spanish construction industry in Morocco is primarily composed of more decentralized, small and medium firms that perform different functions within a spatial and temporal division of labor that is organized to complete different stages of development projects (FNBTP, 2012). These differences help explain the disproportionate and punctuated distribution of investment in the concrete industry, and the smaller, more even distribution of investment in the construction sector. 
Institutional financial investment is an exception to this trend. Financial data from the Ministry of Economy and Competitiveness indicates that a clear sectoralgeographical shift occurred at the onset of the Spanish crisis (MEC, 2015). Figure 5 represents the share of Spanish institutional investment allocated to Moroccan building activity. As was seen in the previous sectoral analysis, a significant shift occurred in the years immediately following the collapse of the housing market. In 2010, as much as 85 percent of institutional investment to Morocco targeted the construction sector. Comparable switching is also evidenced in regional trade data. For example, 83 percent of Catalonian investment in the Moroccan construction industry since 2007 came from the local financial industry (MEC, 2015). Crucially, sectoral-geographical switching evidences different temporal dynamics than that recorded within Spain. Whereas the domestic financial sector continued to steadily invest in non-financial property assets since the European recession (i.e. Figure 1), no such long-term involvement appears to have occurred in the Moroccan context.

\section{FIGURE 5 HERE}

Finally, the theory of capital switching can only be understood within the context of economic overaccumulation (Harvey, 1982). If a switch did indeed occur in an effort to temper the onset of the Spanish housing crisis, then we would expect to find surplus reserves in the domestic construction sector. What evidence is there that suggests the building industry in Catalonia, Madrid, Galicia and Andalusia confronted the problem of "too much capital [...] produced in aggregate relative to 
the opportunities to employ that capital" (Harvey, 1978: 106)? Christophers (2011) examined this issue through the lens of year-end cash reserves held by UK private non-financial corporations. This analysis requires a broader metric to measure overaccumulation within the building industry of the four Autonomous Communities. Gross Operating Surplus (GOS) is a useful indicator because it is designed to identify how much capital is available for firms to either pay debts or finance new operations. Operating surplus is measured as the value generated by a firm's operating activities net intermediate inputs and labor expenditures.

GOS underwent remarkable growth in the four Autonomous Communities during the Spanish housing bubble (SIMA, 2015). The greatest change occurred in Andalusia, with surpluses increasing from $€ 2.6$ to $€ 8.6$ billion between 2000-07. vi This equates to a real compound annual growth rate of 18.6 percent over seven years. Madrid and Catalonia parallel this trend with real CAGRs of 17.2 percent and 15.9 percent, respectively. By comparison, the median regional GOS in construction grew from $€ 467$ million to $€ 1.3$ billion over the same period, representing a CAGR of 15.8 percent. In relative terms, Andalusian GOS was nearly seven times greater than the Spanish regional median at the height of the crisis and exceeded that of Madrid or Catalonia by one billion euros. Even Galicia's construction surpluses, which may appear less dramatic, still doubled from $€ 1.4$ to $€ 2.8$ billion over the period.

The intense growth in construction surpluses is indicative of overaccumulation in the broader industry and the attendant proliferation of urban development into remote Spanish regions. It is now well known that the market's ten-year, six-fold expansion primarily concentrated in second and vacation home 
construction within $2 \mathrm{~km}$ of the Mediterranean coast (Jiménez, 2009: 263). However, by the mid-2000s, the highest urbanization rates were increasingly recorded in rural towns and villages in the Spanish interior. The disproportionate growth of regional construction surpluses helps explain the productive function of urbanization in remote Spanish regions as a mechanism to displace the onset of the housing crisis domestically before switching occurred abroad (Barke, 2007). Similarly, the spatially uneven articulation of these surplus transfers helps explain why, despite the highly localized nature of the Spanish building industry, certain regions expanded their international investment portfolios after 2006 (Romero et al., 2012). For example, regional-level trade data shows that in Andalusia, 97 percent of investment in Moroccan property development emanated from the local construction sector (MEC, 2015). Nearly all of this investment occurred in 2007 alone. By comparison, Galician investment in the Moroccan construction sector was the largest and most consistent over this period, despite comparatively low rates of GOS among the other three Communities. This apparent anomaly suggests a relationship between the rates at which surpluses accumulate, domestic capacity to re-channel capital into the local built environment, and the tendency to switch capital to foreign markets. ${ }^{\text {vii }}$

These trends should not be mistaken for causation, but as plausible indications of real change. Further in-depth research is essential to fully substantiate the claims made in this study. Nevertheless, the distinctive patterns and features that emerge from the data provide an entry point to advance the following interpretation of Spanish investment to Morocco since 2006. Beginning in the late 1990s, a significant overaccumulation of capital appeared in the Spanish construction 
industry. This surplus disproportionately concentrated in a small number of Autonomous Communities, including Catalonia, Galicia, Madrid and Andalusia. Initially, this surplus capital was temporarily regulated through the spatial dispersal of construction investment from the Mediterranean coast into both towns and villages in the Spanish interior and the wider EU. When the housing market collapsed in 2006 and spread into a generalized recession throughout Spain, a number of highly liquid, construction-affiliated firms suddenly confronted a pronounced overaccumulation of capital and few viable options for domestic or European reinvestment. The crisis compelled these firms to seek new opportunities for investment in emerging markets. Morocco presented a particularly advantageous opportunity for firms from Catalonia, Madrid, Galicia and Andalusia to reduce their exposure by throwing their overvalued capital to productive use in the building industry. The impact of this geographical switch was considerable: nearly two billion Euros flowed to Morocco since 2006. The majority of this channeled into industries affiliated with residential and commercial real estate construction. This effort to abate the effects of the crisis were not designed to fundamentally transform the relationship between accumulation and the built form, but to geographically displace its contradictions through the exploitation of markets into new geographical frontiers.

\section{Concluding Remarks}


The theory of capitalist urbanization advanced by Harvey (1978) sought to explain the underlying dynamics shaping contemporary built environments. The framework refuted established interpretations of discrete land change by asserting the inherently productive purpose that urbanization served to regulate the accumulation of capital. The crux of this argument centered upon the concept of "capital switching." For nearly 40 years geographers have attempted to empirically substantiate the theory with little success (Feagin, 1987; King, 1989; Beauregard, 1994). Christophers (2011) recently provided new data in support of the switching thesis, but failed to investigate its geographical dimensions. This study expanded upon previous research by asking how and to what extent the geographical displacement of capital is itself related to sectoral switching crises. The case study examined Spanish foreign direct investment to Morocco at the onset of the European recession. The research findings provide strong evidence that the Spanish housing crisis precipitated a dramatic transfer of investment from four Autonomous Communities to the Moroccan building industry. The spatial concentration of surplus capital in these regions supports broader recognition in the literature of the long-standing political-economic relationship between regional industrialization in northern Spain and speculative urbanization along the country's Mediterranean coast (Romero et al., 2012; Naylon, 1992). This historic axis helps explain the geographical pattern of domestic sectorial switching prior to the 2006 housing crisis. Similarly, Morocco's sweeping efforts to enhance market integration with the European Union was pivotal to establishing the country's "privileged and strategic" 
status with Spain, thereby facilitating the free flow of capital South (Casas-Cortes, et al. 2012; Filali, 2009: 3).

The import of this study concerns how geographers conceptualize the geography of capitalist urbanization. The switching thesis was developed to explain why capital increasingly concentrated in built environments that lacked significant industries or markets around which settlements were understood to agglomerate (Hoyt, 1964; Friedmann and Miller, 1965). Geographers approached the issue as a question of inward investment - where and how it occurred in certain locations over others (e.g. suburban subdivisions, inner-city neighborhoods - Smith, 1987; Wyly et al., 2004). This approach turned the motive force of the switching thesis on its head. Switching by definition refers to capital displacement, when investment shifts from a geographical location or economic sector to another. Where that investment is ultimately "fixed" is a related, but different question.

This is perhaps the crucial problem with Smith's (1982) concept of uneven development when applied to the switching thesis (Feagin, 1987; King, 1989). It is not simply that rent gaps cannot explain the underlying imperatives that drive institutional investors - in collaboration with the state - to exploit undervalued property assets in cities. Rather, it sustains a notion that geographical switching is driven by the comparative locational advantages of a given city, region, or neighborhood that are amenable for investment. This rests upon a conception of the urban as constituted through rent/price differentiation rather than on the devaluation and divestment of overaccumulated capital (Christophers, 2014). Hence, how markets regulate the turnover time of accumulation is crucial to explain the 
spatial reemphasis of investment in undervalued property in addition to its comparative locational advantages (Smith, 1987).

A geographical conception of capital switching also lends important insight into wider debates in urban theory. Pronouncements of an "urban age" have incited theorists to reassess the contemporary urban question (Merrifield, 2013; Brenner and Schmid, 2014; Wachsmuth, 2014). The consensus is that theory has not kept pace with the "actually existing" transformation of cities worldwide (Brenner and Theodore, 2002). Indeed, the logics of contemporary urbanization have transformed since the initial publication of the Urban Process (Harvey, 1978). While this research supports Harvey's (1978) assertion that the built environment plays a crucial role in regulating the volatile, contradictory processes of capitalist accumulation, urbanization can no longer be understood as primarily a sink to "fix" unproductive capital (Harvey, 2008; Christophers, 2011). Rather, urban development has increasingly become a driver of "planetary political-economic, social, and cultural life and socioenvironmental conditions" (Brenner, 2013: 90).

The article revisits the switching thesis as an entry point into understanding some of "the most basic assumptions regarding the site, object, and agenda of 'urban' research" (Brenner et al., 2011: 226). A spatially assertive conception of capital switching offers researchers a framework to chart the pathways and mechanisms through which urbanization proliferates on a global scale. Underlying this process is the recognition that urbanization has a productive purpose in the regulation of capitalist accumulation. How this role has changed is crucial to explaining the uneven development of urbanization as a force of global economic change today. 


\section{References}

Aalbers, M. (2009a) Geographies of the financial crisis. Area, 41.1, 34-42.

Aalbers, M. (2009b) Globalization and the Europeanization of mortgage markets, International Journal of Urban and Regional Research, 33.2, 389-410.

Baker, M., C. Foley, and J. Wurgler (2008) Multinationals as arbitrageurs: The effect of stock market valuations on foreign direct investment. The Review of Financial Studies, 22.1, 337-69.

Barke, M. 2007. Second homes in Spain: An analysis of change at the provincial level, 1981-2001. Geography, 92.3, 196-207.

Beauregard, R.A. (1994) Capital switching and the built environment: United States, 1970-1989. Environment and Planning A, 26.5, 715-32.

Brenner, N. (2013) Theses on urbanization. Public Culture, 25.1, 85-114.

Brenner, N., D. Madden, and D. Wachsmuth (2011) Assemblage urbanism and the challenges of critical urban theory. City, 15.2, 225-240.

Brenner, N. and C. Schmid (2013) The 'urban age' in question. International Journal of Urban and Regional Research.

Brenner, N. and N. Theodore (2002) Cities and the geographies of "actually existing neoliberalism". Antipode, 34.3, 349-379. 
Brueggeman, W.B., A. H. Chen and T. G. Thibodeau (1984) Real estate investment funds: performance and portfolio considerations. Real Estate Economics, 12.3, $333-54$.

Charney, I. (2001) Three dimensions of capital switching within the real estate sector: A Canadian case study. International Journal of Urban and Regional Research, $25.4,740-58$.

Charney, I. (2003) Unpacking and repackaging regional diversity: Office-building trajectories in Canada. Environment and Planning A, 35.2, 231-48.

Chor, D. and K. Manova (2012) Off the cliff and back? Credit conditions and international trade during the global financial crisis. Journal of International Economics, 87, 117-33.

Christaller, W. ([1933] 1966) Central Places in Southern Germany. Englewood Cliffs, N.J.: Prentice-Hall.

Christophers, B. (2011) Revisiting the urbanization of capital. Annals of the Association of American Geographers, 101.6, 1347-64.

Christophers, B. (2014) The territorial fix: Price, power, and profit in the geographies of markets. Progress in Human Geography, Early View.

Entrena, F. and J. Gömez-Mateos (2000) Globalization and socio-economic restructuring in Andalusia: Challenges and possible alternatives. European Sociological Review, 16.1, 93-114. 
Feagin, J.R. (1987) The secondary circuit of capital: Office construction in Huston, Texas. International Journal of Urban and Regional Research, 11, 172-92.

Fédération Nationale du Bâtiments et Travaux Publics (FNBTP) (2012) Interview with FNBTP representative, Tangier, 13 August.

Feenstra, R. (2007) Facts and fallacies about foreign direct investment. In M. Feldstein (Ed) International Capital Flows, Chicago: University of Chicago Press, 331-50.

Friedmann, J. and J. Miller (1965) The urban field, Journal of the American Institute of Planners, 31.4, 312-20.

Filali, N. (2007a) Les promoteurs Iberiques à l'assaut du nord. La Chronique du Nord, 13 January, p. 5.

Galindo, C. (2006) Las inmobiliarias españolas abren mercado en Marruecos como estrategia a largo plazo. El Pais, 4 December.

García, M. (2010) The breakdown of the Spanish urban growth model: Social and territorial effects of the global crisis. International Journal of Urban and Regional Research, 34.4, 967-80.

Gonzalez, L. and Ortega, F., 2013. Immigration and housing booms: Evidence from spain. Journal of Regional Science, 53.1, 37-59.

Gottdiender, M. (1985) The Social Production of Urban Space. Austin: University of Texas Press. 
Harakat, I. (2008) Sale temps pour la spéculation immobilier à Tanger. La Chronique du Nord, 13 September, 6 .

Harvey, D. (1974) Class-monopoly rent, finance and the urban revolution. Regional Studies, 8.3-4, 239-55.

Harvey, D. (1975) The political economy of urbanization in advanced capitalist societies: the case of the United States. In G. Gappert and H. Rose (Eds.) The Social Economy of Cities. Sage: Beverly Hills, CA, 119-63

Harvey, D. (1978) The urban process under capitalism: a framework for analysis. International Journal of Urban and Regional Research, 2.1-4, 101-31.

Harvey, D. (1981) The spatial fix - Hegel, von Thünen and Marx. Antipode, 13.3., 1-12.

Harvey, D. (1982) The Limits to Capital, Oxford, UK: Blackwell.

Harvey, D. (1984) The geopolitics of capitalism. In D. Gregory and J. Urry (Eds.) Space and Social Structures. London: Macmillan.

Harvey, D. (1985) The Urban Experience. Malden, MA: Blackwell.

Harvey, D. (1989) The Condition of Postmodernity. Oxford: Blackwell.

Harvey, D. (2008) The right to the city. New Left Review, 53, 23-40.

Harvey, D. (2010) The Enigma of Capital: And the Crises of Capitalism. Oxford: Oxford University Press. 
Harvey, D. (2012) The urban roots of financial crises: reclaiming the city for anticapitalist struggle. Socialist Register, 48, 1-35

Henn, C., K. Honjo, M. Moreno-Badia, and A. Giustinian (2009) Spain: selected issues. IMF Country Report No. 09/129. International Monetary Fund. Washington: International Monetary Fund.

Hill, H. and J. Jongwanich (2009) Outward foreign direct investment and the financial crisis in developing East Asia. Asian Development Review, 26.2, 1-25.

Hoyt, H. (1964) Recent distortions of the classical models. Land Economics, 40.2, 199212.

King, R.J. (1989) Capital switching and the role of ground rent 2. Switching between circuits and switching between submarkets. Environment and Planning A, 21.6, 711-38.

Kutz, W. and J. Lenhardt (forthcoming) “Where to put the spare cash?" Subprime urbanization and the geographies of the financial crisis in the Global South. Urban Geography.

Lafarge Maroc (2015) Lafarge Maroc en bref. Lafarge Maroc. Accessed 14 December 2015 online at $<$ http: / / www.lafarge.ma/wps/portal/ma/qui-sommesnous>.

López, I. and E. Rodríguez (2011) The Spanish model. New left review, 69.3, 5-29.

Massey, D. (1984) Spatial Divisions of Labor: Social Structures and the Geography of Production. London: Routledge. 
Merrifield, A. (2013) The urban question under planetary urbanization. International Journal of Urban and Regional Research 37.3, 909-922.

Ministerio de Economía y Competitividad (MEC) (2015) Inversión Española en el Exterior. DataInvex Estadísticas de Inversión Española en el Exterior. Accessed 10 June 2015 online at $<$ http: / / datainvex.comercio.es / > .

Naylon, J. (1992) Ascent and decline in the Spanish regional system. Geography, 77.1, $46-62$.

Organisation for Economic Co-operation and Development (OECD) (2015a). Glossary of statistical terms. Organisation for Economic Co-operation and Development. Accessed 14 March 2015 online at $<\underline{\text { https:// stats.oecd.org/glossary/index.htm }>\text {. }}$

Organisation for Economic Co-operation and Development (OECD) (2015b). Institutional investor assets, 1995-2013. Organisation for Economic Co-operation and Development. Accessed 3 May 2016 online at: < http:// www.oecdilibrary.org/finance-and-investment/ data/ oecd-institutional-investorsstatistics/oecd-institutional-investors-statistics_data-00498-en>

Paluzie, E., J. Pons, and D.A.Tirado (2002) The geographical concentration of industry across Spanish regions, 1856-1995. Documents de treball, Facultat d'Economia i Empresa, Espai de Recerca en Economia, E02 / 86, 1-32.

Poulsen, L.S. and G.C. Hufbauer (2011) Foreign direct investment in times of crisis. Peterson Institute for International Economics, Working Paper 11-3, 1-19. 
Rodrígez López, J.R. and Fellinger Jusué, E. (2006) El mercado de la vivienda en España. Previsiones 2007-2009. Universidad de Alcalá, OMPV.

Romero, J., F. Jiménez, and M. Villoria (2012) (Un)sustainable territories: causes of the speculative bubble in Spain (1996-2010) and its territorial, environmental, and sociopolitical consequences. Environment and Planning C, 30.3, 467-86.

Schmidt, R.H. and A. Hackethal (2004) Financing patterns: Measurement concepts and empirical results. Frankfurt Department of Finance Working Paper, 125, 1-49.

Sistema de Información Multiterritorial de Andalucía (SIMA) (2015) Macromagnitudes, Excedente de explotación bruto por ramas de actividad (Base 2000). Sistema de Información Multiterritorial de Andalucía. Accessed 3 May 2016 online at: <http:/ / www.juntadeandalucia.es/institutodeestadisticaycartografia/iea/co nsultasActividad.jsp?CodOper $=104 \&$ sub $=38160>$

Smith, N. (1982) Gentrification and uneven development. Economic Geography, 58, $139-55$.

Smith, N. (1987) Of yuppies and housing: gentrification, social restructuring, and the urban dream. Environment and Planning D, 5.2, 151-72.

Spanish Statistical Office (2000) Methodological Note, Base 2000. Spanish Statistical Office. Accessed 28 May 2015 online at $<$ http:/ / www.ine.es/en/daco/daco42/cre/nota_meto00_en.pdf $>$. 
Spanish Statistical Office (2015a) National accounts, Gross capital formation 19952008. Spanish Statistical Office. Accessed 28 May 2015 online at $<$ http:/ / ine.es/en/inebmenu/mnu_cuentas_en.htm>.

Spanish Statistical Office (2015b) National accounts, Compensation of employees 1995-2008. Spanish Statistical Office. Accessed 28 May 2015 online at

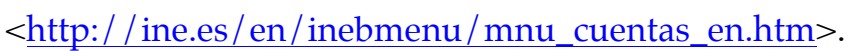

Ucal, M., K.M. Özcan, M.H. Gilgin, J. Mungo (2010) Relationship between financial crisis and foreign direct investment in developing countries using semiparametric regression approach. Journal of Business Economics and Management, 11.1, 20-33.

Wachsmuth, D. (2014) City as ideology: reconciling the explosion of the city form with the tenacity of the city concept. Environment and Planning D: Society and Space, 32.1, 75-90.

Walker, R. (1981) A theory of suburbanization: Capitalism and the construction of urban space in the United States. In Dear, M. and A. Scott (Eds). Urbanization and Urban Planning in Capitalist Society. New York: Methuen, 383-429.

Walker, R. and M. Storper (1989) The Captialist Imperative: Technology, Territory and Industrial Growth. New York: Blackwell.

Weber, A. (1929) Theory of the Location of Industries. Chicago: University of Chicago Press. 
Wyly, E., Atia, M. and Hammel, D. (2004) Has mortgage capital found an inner-city spatial fix? Housing Policy Debate, 15, 623-85.

$\mathrm{Zhu}, \mathrm{H}$. (2005) The importance of property markets for monetary policy and financial stability. Bank for International Settlements, Paper 21, 9-29.

\begin{abstract}
${ }^{i}$ This distinction is precisely why this paper focuses on the concept of geographical switching over the more generic term "spatial fix." Capital switching was the term Harvey (1978) originally employed to explain the transfer of investment from one economic sector or geographical location into another. The "spatial fix" first appeared in an article published in Antipode three years later (Harvey, 1981) and was used as shorthand to denote the outcome of either sectoral or geographical switching. The "fix" does not help us to identify or operationalize the circumstances precipitating geographical capital displacement. Hence, geographical switching is a more useful concept needed to investigate the spatial dynamics of the switching thesis.
\end{abstract}

ii The Spanish Ministry of Economy and Finance defines FDI as any foreign operations involving Spanish residents: (a) participation in unlisted companies domiciled abroad; (b) participation in listed companies domiciled abroad of more than $10 \%$ of capital; (c) establishment or expansion of subsidiary branches, and; (d) other forms of investment in companies or registered contracts abroad (foundations, cooperatives, economic interest groups) in which the invested capital exceeds $€ 1,500,000$.

iii “The standard theory explaining international investment draws on the proposition that firms investing abroad possess a range of specific advantages, and that they prefer to harness these advantages in the form of FDI rather than the alternatives of exporting from their home base or some sort of non-equity arrangements such as licensing, franchise, or royalty agreement. These advantages need to be of sufficient magnitude to overcome the intrinsic cost disadvantages of operating in a less familiar commercial environment abroad. The bases of these advantages include production technology, managerial techniques, financial knowhow, and knowledge of international markets" (Hill and Jongwanich, 2009, 3-4).

iv Classes are indicated by their four numerical digit code. Two digit codes indicate that all classes were sampled within that specific NACE division.

${ }^{\mathrm{v}}$ I am particularly indebted to Chris Knudson for his help working on this aspect of the analysis.

${ }^{v i}$ Methodological changes in the European System of Accounts (ESA) 1995 and ESA 2000 do not allow us to harmonize our analysis to years prior to 2000 (Spanish Statistical Office, 2000).

vii See Kutz and Lenhardt (forthcoming) for an analysis of the specific locational advantages the Moroccan State cultivated to attract Spanish and other European FDI at the onset of the 2007-08 crisis. 
Table 1, Trade Sector Classifications

\begin{tabular}{l|l}
\hline \multicolumn{1}{l}{ Building Activity } \\
\hline Code & \multicolumn{1}{c}{ Description } \\
\hline \hline 08.11 & Quarrying of ornamental and building stone, limestone, gypsum, chalk and slate \\
$16 . X X$ & Manufacture of wood and of products of wood and cork, except furniture; manufacture \\
17.24 & of articles of straw and plaiting materials \\
20.30 & Manufacture of wallpaper \\
22.23 & Manufacture of paints, varnishes and similar coatings, printing ink and mastics \\
$23 . X X$ & Manufacture of other non-metallic mineral products \\
24.20 & Manufacture of tubes, pipes, hollow profiles and related fittings, of steel \\
24.42 & Aluminium production \\
24.43 & Lead, zinc and tin production \\
24.44 & Copper production \\
25.11 & Manufacture of metal structures and parts of structures \\
25.12 & Manufacture of doors and windows of metal \\
25.21 & Manufacture of central heating radiators and boilers \\
25.72 & Manufacture of locks and hinges \\
28.92 & Manufacture of machinery for mining, quarrying and construction \\
$41 . X X$ & Construction of buildings \\
$42 . X X$ & Civil engineering \\
$43 . X X$ & Specialised construction activities \\
46.13 & Agents involved in the sale of timber and building materials \\
46.63 & Wholesale of mining, construction and civil engineering machinery \\
46.73 & Wholesale of wood, construction materials and sanitary equipment \\
46.74 & Wholesale of hardware, plumbing and heating equipment and supplies \\
$68 . X X$ & Real estate activities \\
77.11 & Renting and leasing of cars and light motor vehicles \\
77.12 & Renting and leasing of trucks \\
77.32 & Renting and leasing of construction and civil engineering machinery and equipment \\
$81 . X X$ & Services to buildings and landscape activities \\
\hline &
\end{tabular}

\begin{tabular}{ll}
\hline \multicolumn{2}{l}{ Institutional Investment } \\
\hline Code & \multicolumn{1}{c}{ Description } \\
\hline \hline $64 . X X$ & Financial service activities, except insurance and pension funding \\
$65 . X X$ & Insurance, reinsurance and pension funding, except compulsorysocial security \\
$66 . X X$ & Activities auxiliary to financial services and insurance activities \\
\hline SOurCe: Authors tabulation from NACE Rev .
\end{tabular}

Source: Authors tabulation from NACE Rev. 2 
Table 2, Private Sector Expenditure by Sector, Spain, 1995-2008 (€ millions)

\begin{tabular}{lrrrrrrrrrrrrrrr}
\hline & 1995 & 1996 & 1997 & 1998 & 1999 & 2000 & 2001 & 2002 & 2003 & 2004 & 2005 & 2006 & 2007 & 2008 \\
\hline \hline Buildings & 55053 & 55310 & 58058 & 63549 & 72446 & 83660 & 95159 & 107463 & 121498 & 136757 & 156031 & 176534 & 187693 & 179133 \\
Inputs & 42696 & 46373 & 51299 & 59325 & 66502 & 72953 & 84226 & 86725 & 92901 & 101049 & 111893 & 128434 & 138729 & 137381 \\
Labor & 218493 & 232195 & 250153 & 267173 & 287425 & 312176 & 334707 & 355261 & 378561 & 401102 & 430832 & 464548 & 502182 & 531293 \\
\hline Building Share (\%) & 17 & 17 & 16 & 16 & 17 & 18 & 19 & 20 & 20 & 21 & 22 & 23 & 23 & 21 \\
\hline
\end{tabular}

Source: Spanish Statistical Office. Current values. 
Figure 1, Institutional Investment Rates by Asset Class, Spain, 1999-2013

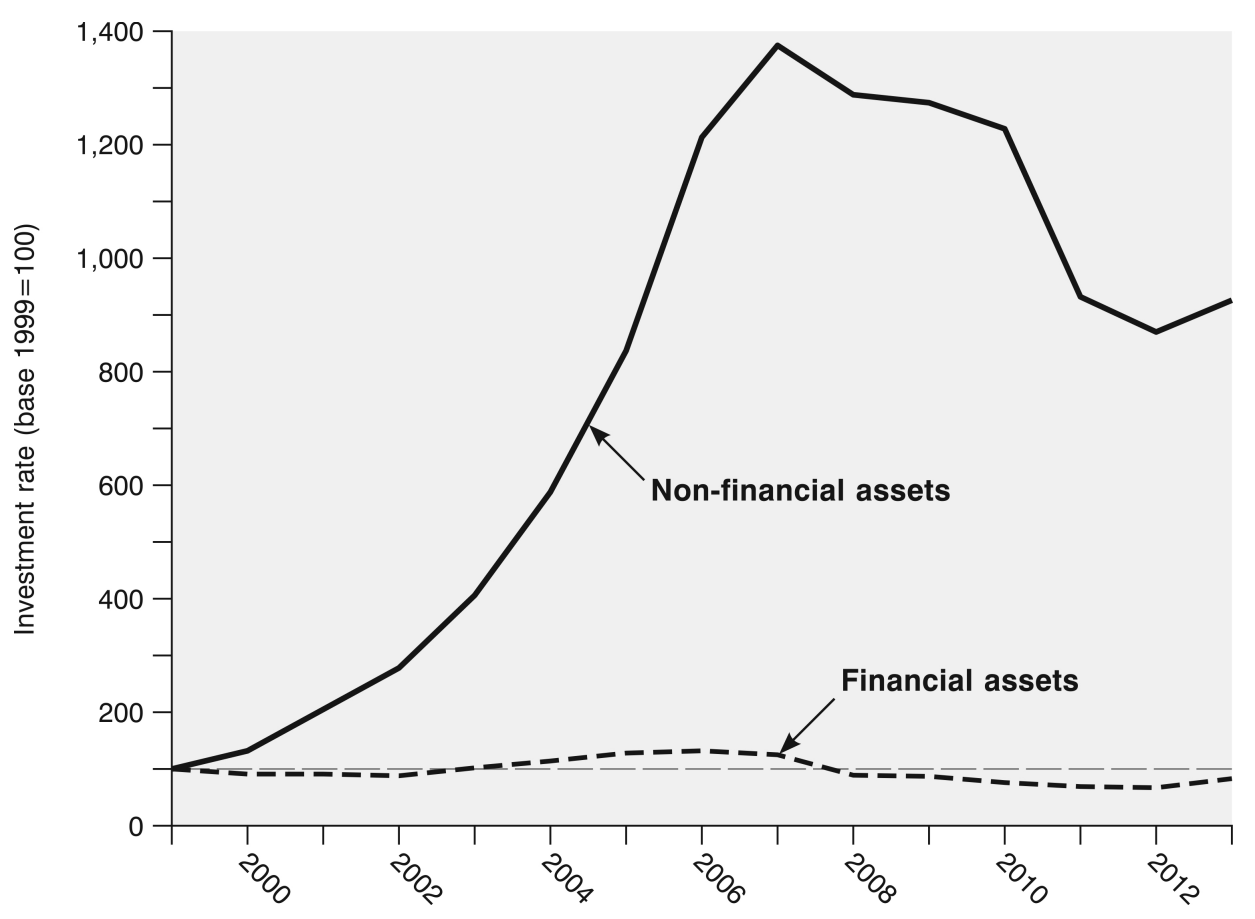

Source: OECD, Annual Institutional Investors' Assets. Current values. 
Figure 2, Institutional Investment Rates by Asset Class, UK, 2000-2013

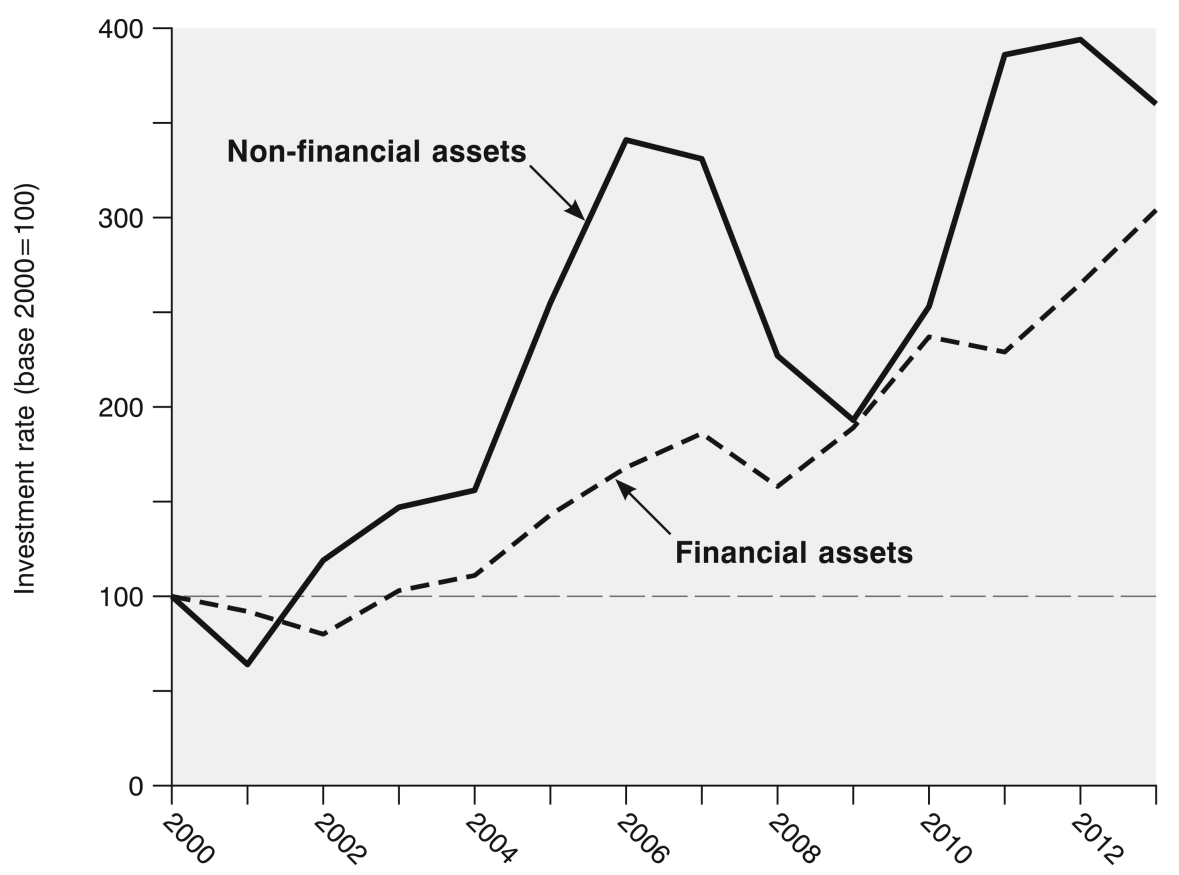

Source: OECD, Annual institutional investors' assets. Current values. 
Figure 3, Foreign Trade by Sector, Spain-Morocco, 1993-2013

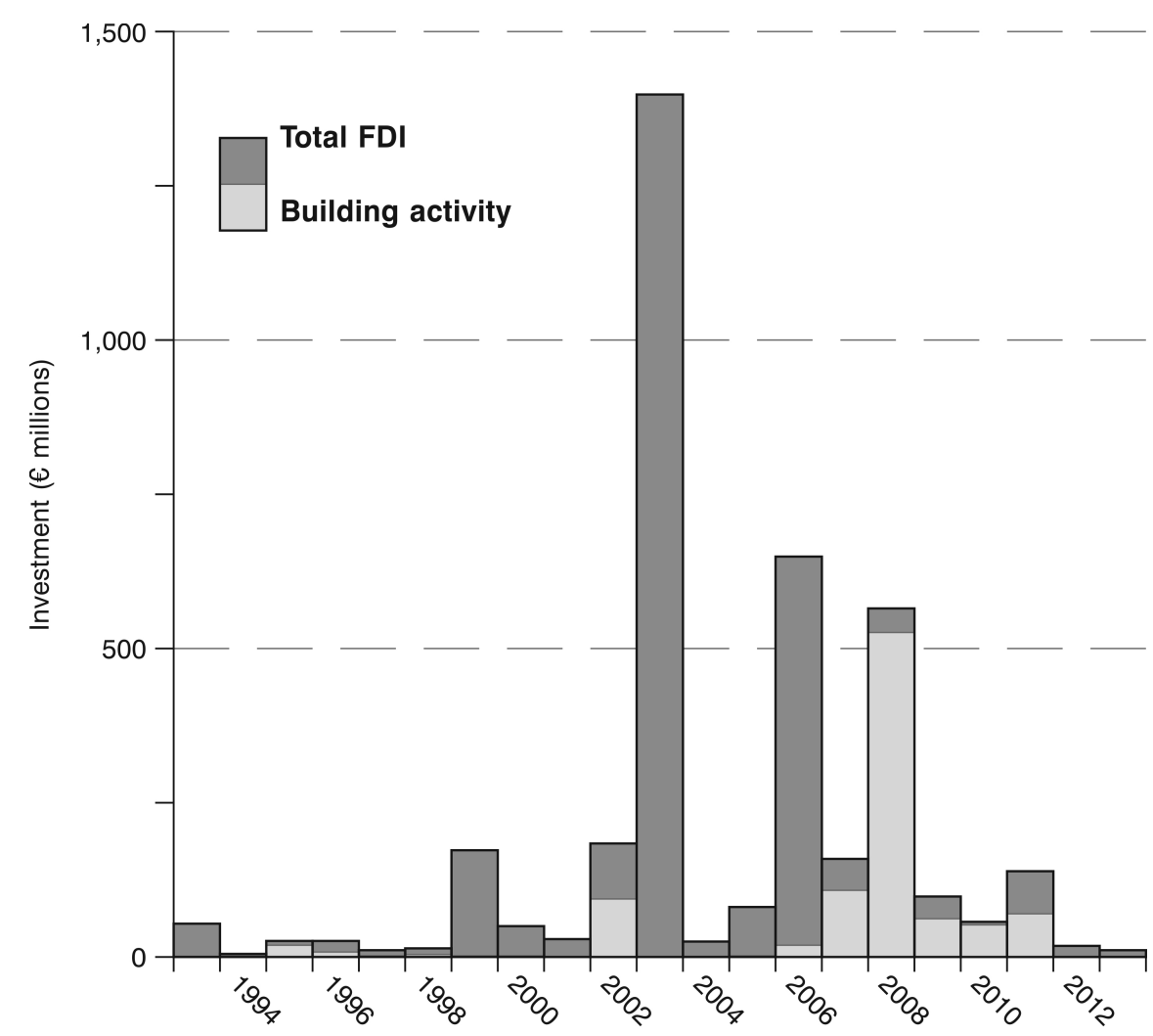

Source: Spanish Ministry of Economy and Competitiveness. Current values. 
Figure 4, Building Investment, EU-15, 1993-2013

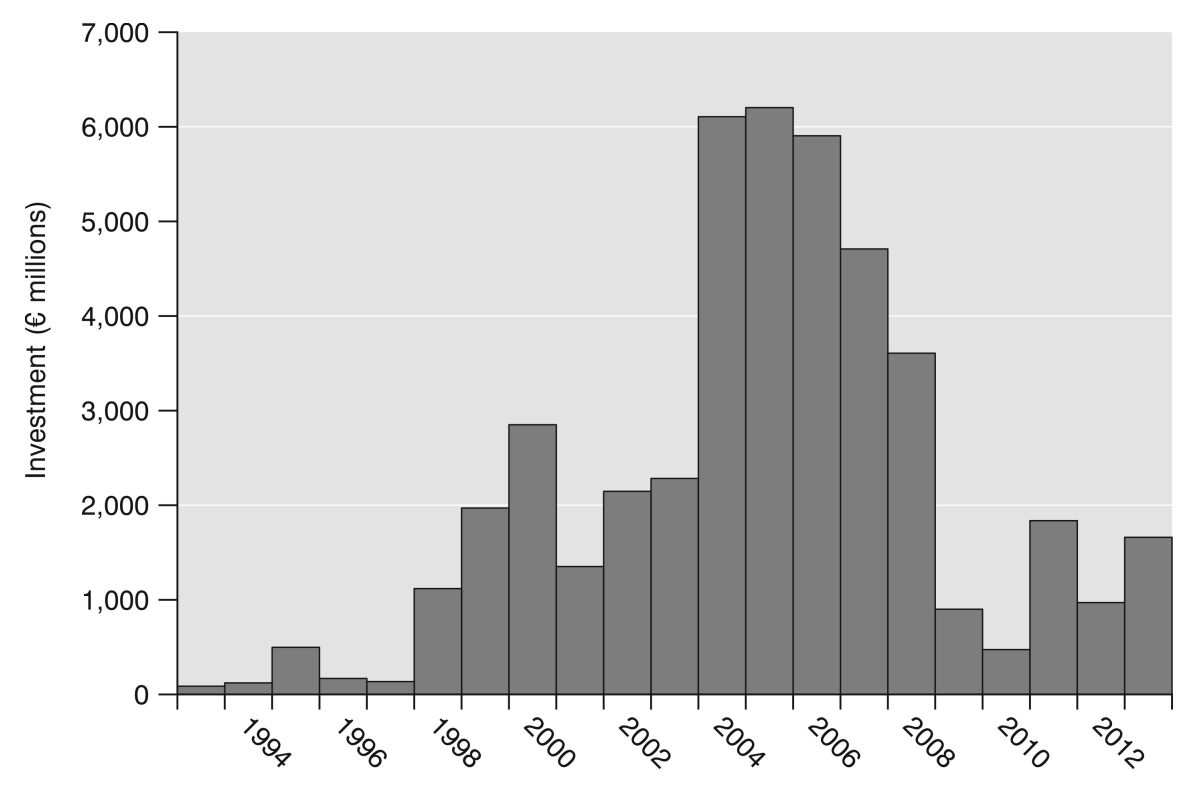

Source: Spanish Ministry of Economy and Competitiveness. Current values. 
Figure 5, Share of Institutional Investment in Building Activity, 1993-2013

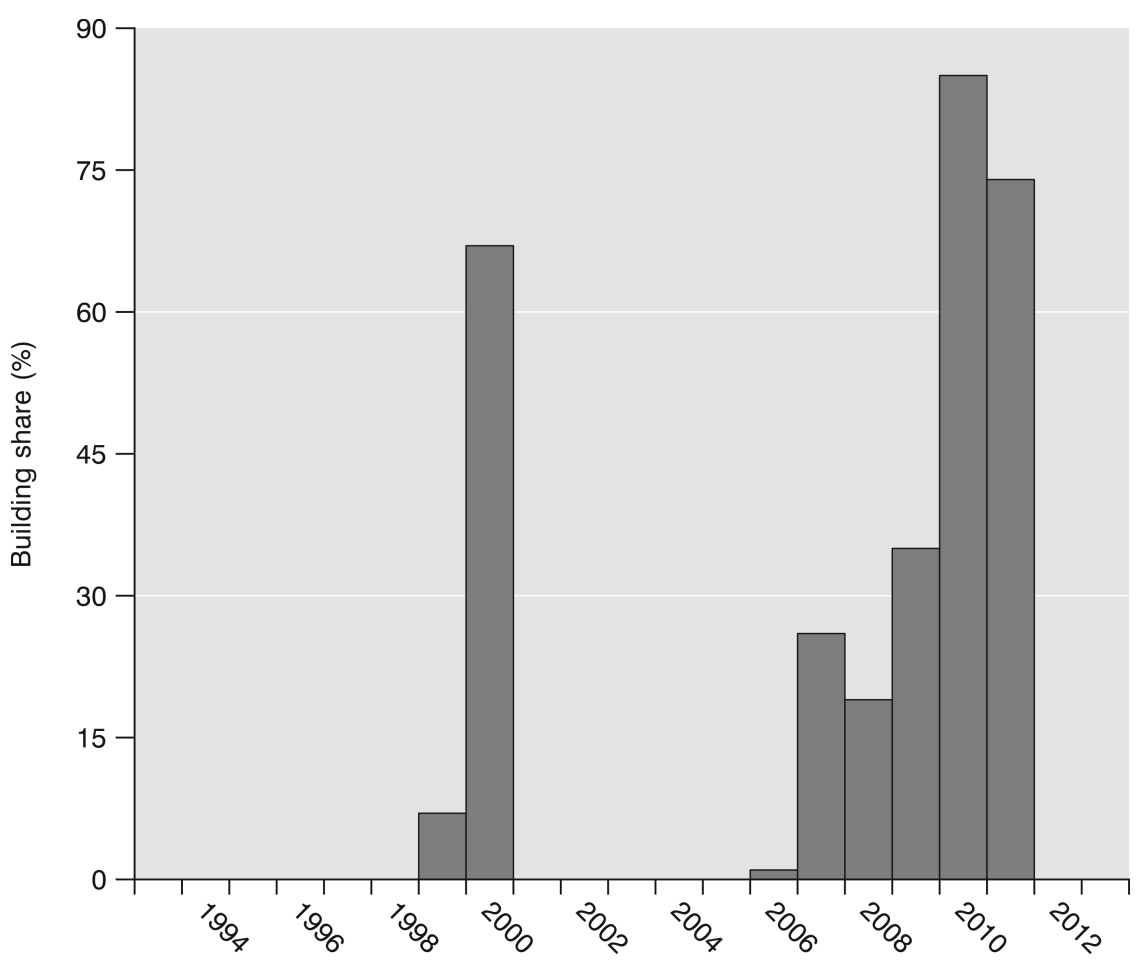

Source: Spanish Ministry of Economy and Competitiveness. Current values. 